\title{
Working Performance of Urban Co-operative Banks (UCBs) in Coimbatore District, Tamil Nadu: A Study
}

\author{
P. Selvaraju \\ Assistant Professor and Head, Department of Co-operative Management, \\ Rajiv Gandhi Arts and Science College, Thavalakuppam, Puducherry, India \\ E-Mail: mpselvaraju@gmail.com
}

\begin{abstract}
Co-operation in its ordinary sense would mean working together. Whereas in its technical sense the term would denote a special mode of doing business, which gives rise to the formal organization and the methods and techniques associated with it. The formal co-operation is the framework for people working together according to certain conditions or principles which the participants agree to observe. Banking is a service industry. The main objective of the banking is to provide the financial support to its customers / members in cooperatives. The urban co-operative banks occupy a significant place in the urban credit movement. The urban co-operative credit movement started in India with the chief object of catering to the banking and credit requirements of the urban middle class, e.g., the small trader of businessman, the artisan or factory worker, the salaried people with a limited fixed income in urban or semi-urban areas. This study is an Empirical Research; study reveals the working performance of the Urban Co-operative Banks (UCBs) in Coimbatore District of Tamil Nadu, India. The core finding of the study will explore the knowledge path and give a financial outlook of UCBs for researchers and policy makers in all respect to take effective decisions.
\end{abstract}

Keywords: Urban Co-operative Banks, Co-operative credit, working performance, loans, business results

\section{INTRODUCTION}

Co-operation in its ordinary sense would mean working together. Whereas in its technical sense the term would denote a special mode of doing business, which gives rise to the formal organization and the methods and techniques associated with it. The formal co-operation is the framework for people working together according to certain conditions or principles which the participants agree to observe. The cooperative movement has spread to all fields of economic activities such as banking, marketing, industrial, production, etc. (Kulaniswamy). Banking is a service industry. The main objective of the banking is to provide the financial support to its customers / members in co-operatives. The urban co-operative banks occupy a significant place in the urban credit movement.

\section{URBAN CO-OPERATIVE BANKS (UCBS)}

The urban co-operative credit movement started in India with the chief object of catering to the banking and credit requirements of the urban middle class, e.g., the small trader of businessman, the artisan or factory worker, the salaried people with a limited fixed income in urban or semi-urban areas (Hajela). Besides protecting the middle class and men of modest means from the clutches of money lenders, the movement is also expected to inculcate the habit of thrift and savings amongst them. The movement provides the frugal section of the community an opportunity of investing their savings and thus helps the hard pressed people tide over the period of stress and strain. The enactment of Cooperative Credit Societies Act, 1904, gave the real impetus to the movement as the first urban cooperative credit society was registered in Canjeevaram town in the then Madras province in October 1904 (Abdul Kuddus and AK Zakir Hussian). The Maclagan Committee's recommendations (1914) have much to contribute in evolving the urban cooperative credit movement and such banks have started developing in all the states of the nation. The urban co-operative banks being primary co-operative credit intuitions function individually as there is no separate secondary or higher tier institutions functioning for them at district and state level (IIBF).

\section{REVIEW OF LITERATURE}

Cooperative credit \& Banking sector, considered to be the backbone of the co-operative movement in India, is passing through a critical phase with no perceptible growth in its structure and business operations. As for urban co-operative banking structure, their number has shrunk due to amalgamation, mergers, liquidation etc., and no bank has been licensed by the Reserve Bank of India (Vishwanathan). The urban cooperative banking sector in India comprises of a number of institutions which vary in terms of their size, nature of business and geographic spread while concentrating on credit delivery in urban areas. As on $1^{\text {st }}$ March 1996, where Banking Regulation Act, 1949 was made applicable to UCBs, there were 1106 primary urban cooperatives banks in India in 1966-67 (Selvaraju). The Urban cooperative Banks, till 1966, were allowed to lend money only for non-agricultural purposes. This distinction does not hold today. These banks were traditionally center around communities, localities work place groups. They essentially lent to small borrowers and business (Rajarajan, Malathi \& Mahalkshmi).

As at end-March 2016, India's co-operative banking sector comprised of 1,574 urban co-operative banks (UCBs) and 93,913 rural co-operative credit institutions, including short- 
term and long-term credit institutions. In pursuance of the recommendations of the Marathe Committee (1992), the Reserve Bank followed an active licensing policy for UCBs to allow them to tap area-specific deposit mobilization and credit absorption potential. As a result, the period 19932004 witnessed a proliferation in the number of UCBs.
Their poor financial health prompted the Reserve Bank to conceive a Vision Document in 2005, which envisaged a multilayered regulatory and supervisory strategy aimed at shoring up their viability. The ensuing mergers/ amalgamations/exits led to a reduction in the number of $\mathrm{UCBs}(\mathrm{RBI})$.

TABLE I PERFORMANCE OF UCBS IN INDIA FOR THE PERIOD FROM 2002-03 TO 2012-13(RS. IN CRORES)

\begin{tabular}{|c|c|c|c|c|c|c|}
\hline Year & No. of UCBS & Share Capital & Owned Fund & Deposits & Borrowings & Loans \& Advances \\
\hline $2002-03$ & 1909 & 2819 & 9269 & 100757 & 1590 & 64022 \\
\hline $2003-04$ & 1926 & 3267 & 12348 & 110256 & 1484 & 67930 \\
\hline $2004-05$ & 1872 & 3221 & NA & 105021 & 1782 & 6674 \\
\hline $2005-06$ & 1853 & 3488 & 13641 & 114060 & 1781 & 71641 \\
\hline $2006-07$ & 1813 & 3884 & 14751 & 121391 & 2657 & 79733 \\
\hline $2007-08$ & 1770 & 4769 & 20108 & 138496 & 2680 & 88981 \\
\hline $2008-09$ & 1721 & 5261 & 20852 & 158733 & 2554 & 97918 \\
\hline $2009-10$ & 1674 & 5567 & 30098 & 183150 & 2340 & 112436 \\
\hline $2010-11$ & 1645 & 6300 & 32600 & 211900 & 4400 & 136500 \\
\hline $2011-12$ & 1618 & 7300 & 34300 & 238600 & 3600 & 157800 \\
\hline $2012-13$ & 1606 & 9300 & 38000 & 276900 & 3100 & 181000 \\
\hline
\end{tabular}

(Source: Report on Trend and Progress of Banking in India, RBI)

The above table is constructed to explore the performance of Urban Co-operative Banks in India and its status for a decade.

\section{UCBS: TAMILNADU AND COIMBATORE DISTRICT}

At time of study, there are 130 UCBs in 32 districts of Tamilnadu state. The urban cooperative banks under study were Coimbatore, Mettupalayam, Pollachi, Udumalpet, Tiruppur and Valparai urban cooperative banks. Coimbatore is the third largest city in Tamilnadu, according to the 2011 census population of the Coimbatore district is 3458045 . With more than 30,000 small, medium and large industries, the city's primary industries are engineering and textiles. The district also houses the country's largest amount of hosiery and poultry industries. Mettupalaym is a taluk headquarters of Coimbatore district. It is located in the foot hills of Nilgiri hills. Pollachi is a leading commercial center and is situated $40 \mathrm{~km}$ south of Coimbatore. Next to Coimbatore it is the leading town of the district. Udumalpet is municipal town and also an industrial town, since a number of textile, paper and variety of industries has been established here and in the agricultural field too. Tiruppur is the Seventh largest city in Tamil Nadu. It is an obscure town in Coimbatore district has been placed in the knitwear map of global apart from catering to the whole India. Valparai is a hill area with tea and coffee plantations on the Anamalai mountain range.

The date of registration and commencement of the business of UCBs in Coimbatore district are given below;

TABLE II URBAN CO-OPERATIVE BANKS (UCBS) IN COIMBATORE DISTRICT

\begin{tabular}{|c|l|c|c|c|}
\hline S. No. & \multicolumn{1}{|c|}{ Name of the Bank } & Date of Registration & Date of Commencement & No. of Branch \\
\hline 1 & Coimbatore City Urban Cooperative Banks (CUCB) & 15.12 .1920 & 08.01 .1921 & 7 \\
\hline 2 & Mettupalayam Urban Cooperative Banks (MUCB) & 24.01 .1923 & 24.01 .1923 & 4 \\
\hline 3 & Pollachi Urban Cooperative Bank (PUCB) & 09.01 .1922 & 21.11 .1922 & 2 \\
\hline 4 & Udumalpet Urban Cooperative Bank (UUCB) & 28.11 .1922 & 20.06 .1923 & 3 \\
\hline 5 & Tiruppur Urban Cooperative Bank (TUCB) & 08.12 .1914 & 08.12 .1915 & 2 \\
\hline 6 & Valparai Urban Cooperative Banks (VUCB) & 29.10 .1948 & 06.05 .1949 & 2 \\
\hline
\end{tabular}

Five of the six selected banks CUCB, PUCB, MUCB, UUCB and TUCB had earlier emergence that is prior to 1930. Whereas the Valparai Urban Cooperative Bank (VUCB) was organized only on 1949.

\section{METHODOLOGY}

This study is an Empirical Research and Survey method was adopted. Secondary data were gathered. The secondary data 
were collected through constructive questionnaire from the records, registers, and financial statements, official websites of the Sample Banks, etc., apart from that, similar other studies / published articles were also considered to this study. Coimbatore is one of the biggest audit zone which covers Urban Co-operative Banks in five districts; Coimbatore, the Nilgiris, Erode, Namakkal and Krishnagiri. Moreover Coimbatore district is the second largest district in the state of Tamil Nadu and had higher banking transactions more urban coverage and early origin. Hence Coimbatore District was purposively selected for the study. This District was bifurcated into Coimbatore and Tiruppur District in 2008. But this study is confined to the earlier Coimbatore District covering Tiruppur also. All the 6 Urban Co-operative Banks in Coimbatore District were selected for the study. The study had covered a decadal period i.e., from 2000-01 to 2010-11.

\section{FINDINGS AND DISCUSSION}

Since the general working aspects like membership, share capital, working capital etc. have bearing on the lending and recovery aspects of the UCBs, these aspects are analyzed in this study. The core findings of the study are summarized below;

1. Membership Position: It was found that growth in membership position of selected UCBs was not significant; about one percent increase during the study period. Except CUCB, the memberships of the banks were on decreasing trend. Growth rate in the membership of the selected UCBs had fluctuating nature and there was no uniformity among the banks. TUCB had been maintaining high membership position during the study period.

2. Share Capital Position: The total share capital position of the Banks had shown a decreasing trend during the study period. Comparatively the Tiruppur UCB had more share capital and Valparai UCB had very less. The quantum of share capital had increased for two banks i.e., CUCB and TUCB during the decadal period which mainly contributed for the overall increases in the district.

3. Reserve Fund: Reserve Fund invariably in all the selected banks (except VUCB) were on increasing trend and the total RF of all the 6 banks put together had almost doubled during the decadal period. Among the banks, MUCB had high growth rate followed by UUCB.

4. Deposits: Deposits mobilisations of 4 banks were at satisfactory level. The PUCB and TUCB met decreasing trend during the study period compared with other banks, CUCB had high growth. In Toto, the growth in the deposits of the selected banks is insignificant i.e. only 6 percent (however with decreasing trend values).

5. Decadal Average Proportion of various Deposits to total deposits: On an average, the fixed deposits, current deposits and savings deposits constituted 80.17 percent, 2.91 percent and 16.92 percent of the total deposits respectively. It was evident that fixed deposits had constitution a major portion of total deposits of the selected urban Cooperative banks

6. Borrowings: The borrowings of the selected banks were Rs.297 lakhs in 2000-01 which had increased to Rs.838 lakhs in 2010-11 i.e. an increase by 182 percent. It is proud to be noted that PUCB had no borrowings at all during the study period. Likewise TUCB also did not borrow during the initial 4 years of the study period. But there after its borrowings showed highly increasing trend. VUCB'S borrowings during the last two years of the study were abnormal. Besides it is interesting to note that UUCB had put effort in reducing their level of borrowings. The CUCB had very low level of borrowings.

7. Working Capital: The working capital of all the banks put together had showed a fluctuating trend. However it had increased by 17 percent during the study period. The working capital of the CUCB, MUCB, VUCB and UUCB had recorded improvements during the decadal period whereas it decreased for the other two banks Viz., PUCB and TUCB. Of the banks, the Coimbatore UCB had the highest working capital level ( Rs.12071 Lakhs) and the Valparai UCB had very low working capital (Rs.879 Lakhs).

8. Investments: The total investment the selected banks showed an increasing trend. The amount was Rs.26.30 lakhs in 2001-01 which had increased to Rs.7461 lakhs in 2010-11 (increase by 184 percent). The investments made by CUCB, MUCB, PUCB and UUCB had recorded a continuous increase whereas the position with the Valparai UCB is disheartening: about 90 percent decline during the study period is noticed. Comparatively the CCUB had high investments (Average per year was Rs.2811 crores).

9. Sector-wise Investments Position: More than 75 percent of the investments of the banks were in Government Securities. Investments in shares of other Cooperatives constituted only 6 percent.

10. Loan Operations: Loans and advances issued by the selected banks had been increasing year after year; the total loan issued was Rs.16339 lakhs in 2001-01 which had increased to 35292 lakhs is 2010-11, (an increase by 116 percent). Comparatively the CCUB had given more loans (yearly average Rs.8955 lakhs). On the contrary, the loan issued by the Valparai UCB was very less and with much of yearly variations.

11. Purpose -wise Lending for Various Purposes: 70 percent of the loans issued by the banks were of Jewel loans. Housing loans rank second (16.65 percent). PUCB, UUCB and TUCB had comparatively given more of housing loans. Weaker section loans were given by Udumalpet and pollachi UCBS and to that extent their Jewel loans got reduced.

12. Total Loans Outstanding: The total yearly loans outstanding showed a fluctuating trend. However it had increased by 11 percent during the study period. The loans outstanding were very high with the 
Coimbatore UCB and very low with the Valparai UCB (average of Rs.487 lakhs). The loan outstanding of all the UCBs in Coimbatore district stood at Rs. 208 crores in 2010-11. Rank of the banks with regard to loans outstanding was CUCB, TUCB, MUCB, PUCB, UUCB and VUCB.

13. Total Assets of the Banks: Among the 6 banks, the CUCB possessed more assets. The total assests of all the selected banks had increased from Rs.31737 lakhs in 2000-01 to Rs.42519 lakhs in 2010-11 (i.e. an increase by 34 percent). The Valparai UCB had very low level of assets i.e. The decadal average of Rs.899 lakhs.

14. Establishment and contingency: The establishment and contingency expenses of the selected banks showed an increasing trend the trend value stood at 453 which had increased to 1429 in 2010-11. However yearly fluctuation was noticed with CUCB, UUCB and VCUB.

15. Business Result: 5 of the six selected banks were running on profit. The one, Valparai UCB incurred loss during the alternative years and attained stability from 2009-10. However the bank was under cumulative loss. The average yearly profit of Coimbatore UCB was comparatively high followed by TUCB and PUCB. The yearly average profit of the UCBs in Coimbatore District was Rs.213.4 lakhs.

16. Performance of the Banks Assessed by the Audit Wing: Audit classification of co-operative banks is an indicator and reflects its performance. There are four categories of classification of audit rated by the audit officials of the audit wing. The categorization is done on the basis of records, position of over dues, Nonperforming Assets etc., On the basis of total scored received by the institutions, the $70 \%$ and above on classified under ' $\mathrm{A}$ ' category, $50-69 \%$ on classified under ' $\mathrm{B}$ ' category, $42-49 \%$ are under ' $\mathrm{C}$ ' category and the rest under ' $\mathrm{D}$ ' category. To which category the selected banks were placed. The audit classification of UCBs in Coimbatore district over the years has analyzed.

The Mettupalayam UCB was rank first with more of ' $A$ ' class awarded and the TUCB had started maintaining ' $A$ ' classification in recent years. It is disheartening to note that the VUCB was mostly under ' $\mathrm{C}$ ' classification thereby proving its poor performance.

\section{CONCLUSION}

The urban cooperative banks under study were Coimbatore, Mettupalayam, Pollachi, Umumalpet, Tiruppur and Valparai urban cooperative banks. Five of the six selected banks CUCB, PUCB, MUCB, UUCB and TUCB had earlier emergence that is prior to 1930. Whereas the Valparai Urban Cooperative Bank (VUCB) was organized only on 1949. Growth rate in the membership of the selected UCBs had fluctuating nature and there was no uniformity among the banks. The total share capital position of the Banks show a decreasing trend during the study period. The growth in the deposits of the selected banks is insignificant i.e. only 6 percent however with decreasing trend values. The borrowings of the selected banks were Rs.297 lakhs in 2000-01 which had increased to Rs.838 lakhs in 2010-11 i.e. an increase by 182 percent. It is proud to be noted that PUCB had no borrowings at all during the study period. Invariably in each bank, a high proportion to the total working capital was from deposits but the UUCB had only 60.4 percent of the working capital as deposits. More than 75 percent of the investments of the banks were is Government Securities. It is disheartening to note that the VUCB was mostly under 'C' classification proving its poor performance.

\section{REFERENCES}

[1] V. Kulaniswamy, "Relevance Co-operative Management", Cooperative Management, $1^{\text {st }}$ ed. INDIA, pp. 26-29, 2002.

[2] O.R Krishna swami and V. Kulandaiswamy, "Principles of Cooperation", Cooperation Concept and Theory, INDIA, pp.33-35, 2000 .

[3] D.Anandagopal and P.Selvaraju, "A study on micro credit operations of the Urban Co-operative Banking in Coimbatore District, Tamil Nadu", Indian Co-operative Review, Vol. 48, No. 2, pp.113-123, 2011.

[4] K. A. Abdul Kuddus and AK Zakir Hussian, "Urban Co-operatives Banks (UCBs)", in Cooperative Credit and Banking, $2^{\text {nd }}$ ed., Limbra Publications, India, pp.229-245, 2015.

[5] T.N Hajela, "Urban Financial Cooperatives", Cooperation Principles, problems and Practice, $7^{\text {th }}$ ed., Ane Publications, INDIA, pp.630-637,2010.

[6] IIBF, Brief Overview of the structure of Co-operative Credit Intuitions, in Co-operative Banking, $1^{\text {st }}$ ed., Macmillan Publishers India, INDIA, pp. 13-17, 2011.

[7] Reserve Banks of India (RBI), Report on Trends and Progress of Banking in India, 2011, 「Onlinel Available:https://www.rbi.org.in/Scripts/AnnualPublications.aspx?he ad=Trend+and+Progress+of+Banking+in+India

[8] B.S. Vishwanathan, "Cooperative Bank of India - A necessity for Sectoral Growth", in $16^{\text {th }}$ Indian Cooperative Congress, New Delhi, INDIA, pp. 9-11, 2013.

[9] P. Selvaraju, "Pattern and Perception of Defaulted Member Borrowers of Urban Cooperative Banks (UCBs) in Coimbatore District of Tamil Nadu- A Study”, Indian Cooperative Review, Vol. 52, No.1, pp. 63-65, 2014.

[10] M.Rajarajan, T. Malathi anad A. Mahalkshmi, "Role of Urban Cooperative Banks in Financial Inclusion", Tamilnadu Journal of Cooperation, pp. 25-27, 2014.

[11] Reserve Bank of India, "Developments in Co-operative Banking”, Report on Trend and Progress of Banking in India, 2017 [Online] Available:

https://www.rbi.org.in/Scripts/AnnualPublications.aspx?head=Trend $\% 20$ and $\% 20$ Progress\%20of\%20Banking\%20in\%20India

[12] CCUCB, MUCB PUCB,UUCB,TUCB and VUCB, "Audit Report of the Urban Co-operative Banks", INDIA, 2002-03 to 2011-12.

[13] Reserve Banks of India (RBI), Report on Trends and Progress of Banking in India,2016,

[Online]Available:https://www.rbi.org.in/Scripts/AnnualPublications. aspx ?head=Trend + and + Progress + of + Banking + in + India 